\title{
Liberdade Religiosa, Fundamentalismos e Controvérsias acerca da Abertura de Templos em meio a Pandemia do Covid-19 no Brasil
}

\author{
Celso Gabatz* \\ Jefferson Zeferino** \\ Rogério de Carvalho Veras***
}

\section{Resumo}

O propósito desta abordagem é esboçar questões pertinentes à realidade conjuntural brasileira na perspectiva pandêmica, seus desdobramentos e interlocuções com aspectos engendrados por algumas denominações religiosas, sobretudo, evangélicas neopentecostais no cenário atual face à flexibilização da abertura de templos e a realização de cultos. Busca-se aqui, entrementes, ampliar o horizonte crítico e compreensivo sobre as possíveis alternativas que possam (de)limitar um entendimento de bem comum. Interessa-nos, sobretudo, entabular um aprofundamento de como esta conjuntura pandêmica vem repercutindo no panorama brasileiro a partir de determinados valores instrumentalizados no âmbito das sociabilidades religiosas e que, por vezes, consolidam convicções ou preconceitos quem acentuam a própria incapacidade cognitiva em lidar com a realidade. Os resultados indicam que os parâmetros utilizados pelas instituições religiosas se embasam em uma visão tutelar e de correção moral, objetivando reforçar valores que, pretensamente, se coadunariam com o desejo das famílias, dos costumes, de uma ordem política e religiosa enquanto expressão da maioria da população. Palavra-chave: Laicidade; Fundamentalismos; Pandemia do Covid-19; Abertura de Templos.

* Pós-Doutorando e Professor Colaborador no Programa de Pós-Graduação da Faculdades EST, São Leopoldo, RS. Doutor em Ciências Sociais (UNISINOS). Mestre em História (UPF). Graduado em Sociologia, Filosofia e Teologia. CV: http://lattes.cnpq. br/7404950936752263 E-mail: gabatz12@hotmail.com

** Pós-Doutorando em Teologia na PUCPR. Doutor em Teologia (PUCPR). Mestre em Teologia (PUCPR). Graduado em Teologia e História. CV: http://lattes.cnpq. br/3365290019359083 E-mail: jefferson.zeferino@hotmail.com

*** Professor da Universidade Federal do Maranhão (UFMA). Doutor em História (UNESP). Mestre em Ciências Sociais (UFMA). Graduado em História e Direito. CV: http://lattes. cnpq.br/3009770629664175 E-mail: rogerioveras14@gmail.com 


\section{Religious freedom, Fundamentalism, and the controversy on the opening of temples amidst Covid-19 Pandemic in Brazil}

\section{Abstract:}

This approach aims to sketch some pertinent questions regarding Brazilian conjuncture on the horizon of the pandemic, its developments and interlocution with aspects engendered by religious denominations, such as neo-Pentecostalism, especially on the matter of the reopening of temples with its services. The work also aims to amplify the critical horizon on the possible alternatives that may (de)limit an understanding on common good. So, we seek to deepen the understanding on how the pandemic concerns to Brazilian situation departing from some values that are instrumentalized in the field of religious sociability that, sometimes, consolidate convictions and prejudices that may accentuate the cognitive inability to deal with reality. The results show that the parameters used by some religious institutions are based on a tutelary vision and on moral correction emphasis, trying to reinforce values that allegedly corroborate the desires of families and customs as a political and religious order as an expression of most of the population.

Keywords: Laicity; Fundamentalism; Covid-19 Pandemic; Opening of Temples.

\section{Libertad religiosa, Fundamentalismos y controversias sobre la apertura de templos en medio de la pandemia de Covid-19 en Brasil}

\section{Resumen:}

El propósito de este enfoque es esbozar cuestiones relevantes para la realidad coyuntural brasileña en la perspectiva de la pandemia, sus desarrollos e interlocuciones con aspectos engendrados por algunas denominaciones religiosas, especialmente, evangélicas neopentecostales en el escenario actual frente a la flexibilización de la apertura de templos y la celebración de cultos. Sin embargo, buscamos aquí ampliar el horizonte crítico y comprensivo sobre las posibles alternativas que pueden (de) limitar la comprensión del bien común. Nos interesa, sobre todo, profundizar cómo esta coyuntura pandémica viene repercutiendo en el panorama brasileño a partir de ciertos valores instrumentalizados dentro de las sociabilidades religiosas y que, en ciertas ocasiones, consolidan convicciones o prejuicios que acentúan la propia incapacidad cognitiva para comprender la realidad. Los resultados indican que los parámetros utilizados por las instituciones religiosas se basan en una visión tutelar y de corrección moral, con el objetivo de reforzar los valores que, supuestamente, estarían en consonancia con el deseo de las familias, de los costumbres, de un orden político y religioso como expresión de la mayoría de la población.

Palabras-clave: Laicidad; Fundamentalismos; Pandemia de Covid-19; Apertura de Templos. 


\section{Considerações iniciais}

Em novembro de 2021, já em um clima de arrefecimento da doença, o Brasil contabiliza quase 22 milhões de casos e cerca de 609 mil mortes causadas pela Covid-19 (G1, 2021). Segundo o epidemiologista Pedro Hallal (cf. SENADO FEDERAL, 2021), da Universidade Federal de Pelotas, milhares de vidas poderiam ter sido salvas com o fomento de boas práticas de prevenção e melhor manejo da vacinação (especialmente na compra das vacinas desde a primeira hora). Chega-se a indicar que 4 a cada 5 mortes poderiam ter sido evitadas. Os números nos fazem ver que a crise na saúde não se limita ao aspecto sanitário de uma doença que poderia ser combatida com o uso de máscaras, distanciamento social, álcool em gel, lavagem das mãos com água e sabão. Mesmo reconhecendo o déficit estrutural histórico recorrente, como a falta de saneamento básico, que favorece as más condições de higiene, não se pode limitar a catástrofe vivida apenas a esses fatores.

Os elementos políticos e ideológicos que repercutem no contexto da pandemia têm sido amplamente debatidos, sendo, inclusive, pautados pela Comissão Parlamentar de Inquérito que, em seu relatório final, indicia inúmeros possíveis corresponsáveis pela má administração dos recursos e do não seguimento às orientações propostas por especialistas e órgãos competentes. Entre os denunciados, encontra-se, inclusive, o presidente da república (cf. CPI DA PANDEMIA, 2021).

A falsa escolha entre a vida e a economia teve seus reflexos também no âmbito religioso. Enquanto lideranças eclesiais, como veremos adiante, sustentam a argumentação de que igrejas seriam como hospitais e, por isso mesmo, não poderiam ficar de portas fechadas, o que se percebe é um comportamento que, diante de uma lógica de mercado, vê-se prejudicado financeiramente quando da não oferta de seus serviços. Há uma consolidação de forças religiosas no espaço público brasileiro. Estas acabaram se notabilizando, entrementes, também em virtude das mudanças decorrentes da nova demografia religiosa nos dias atuais, adquirindo um protagonismo cada vez maior ao lado daqueles grupos já consagrados. Nomeadamente, além do ainda majoritário catolicismo, também os assim chamados evangélicos vão equilibrando a balança de privilégios públicos e políticos, não por último, em razão de seu crescimento numérico, sua performance econômica e a sua incidência política. Grupos hegemônicos vão, desse modo, atuando em causa própria, bem como, demarcando espaços e domínios de maneira estratégica. Enquanto isso, identidades religiosas minoritárias ou mesmo fora do espectro 
das religiões e religiosidades cristãs seguem carentes da idealizada isonomia pretendida pela carta constitucional brasileira.

Em um primeiro momento, esta abordagem apresenta um percurso histórico acerca das relações entre as religiões e o espaço público, privilegiando o desenvolvimento dos textos constitucionais no que diz respeito à liberdade religiosa. Na sequência, aprofunda-se a relação entre o fundamentalismo e o capitalismo, de modo a descrever um cenário de fundo que pode estar na base do fenômeno que, na sequência, é ilustrado por um estudo de caso. O terceiro momento, portanto, apresenta justamente a argumentação desenvolvida em uma série de reportagens que propunham flexibilizar a abertura de templos e a realização de cultos no contexto da pandemia da Covid-19.

\section{As Relações entre o Estado e as Religiões no Contexto Brasileiro e Republicano}

A história não avaliza que o Estado brasileiro tenha se organizado em um patamar de neutralidade à influência daqueles que detinham o poder de movimentar um modo de pensar coletivo. Trata-se, muito mais, de veias abertas, conforme a linguagem preconizada pelo jornalista e escritor uruguaio, Eduardo Galeano (2015, p. 18), subsistindo a lógica, segundo a qual, uma minoria dominante subjugava as massas que, grosso modo, não conseguia o necessário protagonismo para se fazer respeitar no seu meio social.

Tais condições, em geral, foram agravadas a depender do contexto, especialmente se considerarmos que, no Brasil, a pretensa igualdade foi se efetivando mais no plano formal e construída em sua materialidade no âmbito de um espaço que há muito vivencia distanciamentos em relação à democracia. Convém, nessa direção, sublinhar aquilo que é referido pelo sociólogo alemão, Jürgen Habermas, ao constatar que há uma incidência estratégica do poder religioso na esfera pública de modo a, entrementes, exacerbar certa:

[...] expectativa normativa com a qual a comunidade religiosa se vê confrontada pelo Estado liberal e confunde-se com seus próprios interesses, na medida em que lhe dá a possibilidade de exercer por meio da esfera pública política sua própria influência sobre a sociedade como um todo. (HABERMAS; RATZINGER, 2007, p. 54)

Historicamente, os valores transmitidos pelas religiões no Brasil representam pautas axiológicas específicas que, na maioria das vezes, 
demandaram a estruturação de valores predominantes daqueles que os representam e por parte do próprio Estado. Todavia, o que fazer quando a escala de proeminência de valores não coincide com as diversas expressões de fé professadas? Ou ainda: como fazer quando houver a necessidade de se ponderar conflitos entre a liberdade de expressão, consciência e de opinião de uma pessoa com a liberdade religiosa de outra? São questões importantes que esta abordagem buscará aprofundar.

Durante os períodos colonial e também imperial, o catolicismo passou a ser a religião prevalecente no Brasil. Embora a Constituição de 1824 tenha feito avanços em relação aos cultos de tradição não católica, especialmente no âmbito protestante, reiterando que estas denominações poderiam expressar o seu pertencimento em suas próprias línguas e no recinto doméstico, foi apenas com a primeira constituição republicana, em 1891, que ocorreu a separação formal entre Igreja e Estado. Surgem indagações acerca do monopólio da igreja católica e prevalece a garantia de uma maior liberdade religiosa para as demais confissões religiosas, além da extinção do regime de padroado, a secularização dos aparelhos estatais e o reconhecimento dos casamentos (BIRMAN, 2003).

Isto não significou, todavia, que houve a retirada de inúmeros privilégios em relação às congregações católicas. Diferentes grupos católicos souberam agir de forma estratégica na Constituinte de 1891 para impedir a aprovação, por exemplo, da lei da mão-morta, pela qual se pretendia despojar os bens materiais da Igreja. Tanto as ordens como as diferentes congregações religiosas continuaram atuando de forma muito incisiva. As subvenções por parte do Estado permaneceram e em certas localidades a obtenção de documentos oficiais continuou a ser possível apenas pelas mãos dos religiosos. Mesmo com a separação constitucional em relação ao Estado “a Igreja ainda ocupava espaços consideráveis nas áreas da saúde, educação, lazer e cultura" (MARIANO, 2001, p. 146). Importa ressaltar que o interesse do Estado na separação nunca foi na direção de atender minorias religiosas ou ser o árbitro e garantidor da concorrência religiosa.

De acordo com a compreensão reiterada pelo jurista, Fábio Carvalho Leite, a constituição da primeira república "definiu as bases das relações entre Estado e religião reproduzidas nos textos posteriores” (2014, p. 207). Esta demanda suscitou "que as religiões minoritárias pretendessem um sentido mais amplo de liberdade religiosa a fim de buscar proteção aos seus ritos, crenças e objeções. O alcance atribuído na prática à liberdade religiosa 
era insatisfatório" (LEITE, 2014, p. 207-208). Significa dizer que mesmo exaltando a liberdade religiosa e consolidando uma premissa de separação entre a Igreja e o Estado, o código penal republicano tipificava como crimes as práticas ligadas ao espiritismo, magia, cartomancia e o curandeirismo.

Não havia [...] em relação à liberdade de culto, possibilidade de garantir espaço oficial para crenças e religiões que fossem, simultaneamente, doutrinárias e práticas, $[\ldots]$ que tivessem um pé na modernidade teórico-científica e na busca de princípios e pressupostos lógicos [...] e outro pé no empirismo de tradições legitimadas por reiteradas atribuições de significados a acontecimentos cartesianamente desconectados. (SCHRITZMEYER, 2004. p. 138)

Conforme as deliberações preconizadas neste contexto, as tradições de matriz africana, indígena e espírita, eram identificadas a partir de uma percepção que as colocava em uma proximidade com um universo marcado pela irracionalidade e o atraso. Tratava-se, assim, de um entendimento muito diferente daquele que se buscava descortinar no âmbito da fé cristã, de forma especial e mais incisiva, na tradição católica e nas igrejas ligadas ao protestantismo histórico, tidas como diretamente vinculadas aos meandros da modernidade, com o mundo racional, o progresso e os padrões eurocêntricos (MONTERO, 2009, p. 7-16).

Em meio a esta realidade, convém destacar que a doutrina constitucionalista presente no texto da primeira república não permitiu identificar uma posição segura sobre os possíveis limites à liberdade de cultos ou crenças. Aliás, as considerações, em geral, eram bastante vagas e até superficiais em relação ao tema. Algo que acabou se tornando recorrente nas abordagens jurídicas e suscitou dilemas para a afirmação da liberdade religiosa no país em períodos posteriores.

O resultado deste estado de coisas foi a consolidação de uma doutrina que se limitava a reconhecer que a liberdade religiosa não seria um direito absoluto, despreocupando-se, todavia, em estabelecer, em graus seguros, os seus potenciais limites. E, em relação a outras questões envolvendo Estado e religião [...] verificou-se uma doutrina por vezes extremamente idiossincrática, despreocupada em pautar a interpretação jurídica a partir de critérios metodológicos. (LEITE, 2014, p. 248)

No texto constitucional de 1934, com base em uma intensa reinvindicação católica, restou introduzido o princípio da "colaboração 
recíproca" entre o Estado e a religião (GIUMBELLI, 2011). Afirmou-se, desta forma, uma estreita proximidade entre a Igreja Católica e o, assim denominado, Estado Novo, comandado por Getúlio Vargas. ${ }^{1}$ Foi nesta época que a Igreja Católica romana conseguiu avançar muito na sua privilegiada relação com o Estado de modo que tenha alcançado um status de religião "quase oficial" (MARIANO, 2001, p. 145).

Para as outras denominações religiosas, como no caso do espiritismo e, de forma mais marcante, para as religiões de matriz africana, o Estado Novo foi caracterizado por fortes repressões das forças policiais. Com um discurso que supunha que os lugares de culto afro-brasileiros acobertavam comunistas, justificava-se a truculência do poder repressor estatal (STEIL, 2001, p. 115-129). ${ }^{2}$ A discriminação e perseguição se coadunavam com a ideologia governamental em um tempo marcado por decisões políticas que pretendiam estabelecer uma ideologia do 'branqueamento' e inserir o país na perspectiva da modernização (DÁVILA, 2006).

As mudanças decorrentes da intervenção do estado na economia com a supressão dos partidos e a consolidação de um regime político ditatorial fizeram com que o texto constitucional de 1937, mesmo tendo a proteção à liberdade religiosa como norma, não (de)limitou as investidas das autoridades públicas para criminalizar expressões religiosas minoritárias (BONAVIDES; ANDRADE, 1991). A Constituição de 1946, por sua vez, buscou superar

1 "De forma inédita, a Constituição de 1934 passou a admitir a existência de assistência religiosa nas expedições militares, nos hospitais, nas penitenciárias e em outros estabelecimentos oficiais (...). Trouxe previsão da existência de cemitérios particulares, inclusive sob a administração de instituições religiosas (...), admitiu os efeitos civis ao casamento religioso e a possibilidade da instrução religiosa nas escolas públicas, por meio do ensino religioso (...) ministrado de acordo com os princípios da confissão religiosa do aluno" (RODRIGUES, 2014. p. 90-91).

2 Haroldo Reimer, ao comentar a Constituição de 1934, afirma o seguinte: "O inciso, contudo, estabelece uma restrição ao exercício da liberdade religiosa nos limites da extensão do termo nesse texto constitucional. Isso é indicado pela frase 'desde que não contravenham à ordem pública e aos bons costumes’ no Inciso $5^{\circ}$. Em princípio, a sobreposição da 'ordem pública' aos interesses privados, ainda que expressos coletivamente, condiz com as normas do direito público e nada haveria a obstar. Porém a vinculação com os 'bons costumes' situa essa 'ordem pública' no nível da lei moral. Na prática, isso provavelmente significava que determinadas expressões religiosas estavam alijadas do pleno exercício da liberdade religiosa, o que, em regra, afetava os cultos de matriz africana. Esses, por conta de sua ritualidade envolvendo tambores, danças, sacrifícios de animais etc., não raras vezes podiam dar causa para queixas, vindo a ser frequentemente 'caso de polícia', com enquadramento na Lei das Contravenções Penais” (REIMER, 2013, p. 61). 
algumas crises existentes em períodos anteriores, mas, por outro lado, teve a sua vigência em um tempo bastante conturbado da realidade brasileira. Morte de Getúlio Vargas em 1954, a renúncia de Jânio Quadros no ano de 1961 e a deposição de João Goulart com a consequente instauração do regime militar de exceção em 1964. Via de regra, por meio da carta constitucional:

[...] garantia-se a liberdade de pensar o mundo, mas, por outro, controlava-se a liberdade de agir nesse mundo, pois, ao mesmo tempo em que se apostava em um Brasil capaz de se modernizar, constatava-se que ainda se tratava de um país atrasado. Os mesmos cidadãos precisavam, simultaneamente, aos olhos da lei, sair do subdesenvolvimento, educar-se e ser acompanhados de perto em seus primeiros voos nos céus da modernidade. Especialmente os cultos mágico-religiosos e as práticas curativas que guardassem vínculos com um passado colonial ou imperial eram considerados sinônimos de subdesenvolvimento e, consequentemente, focos de retardamento cultural a serem extirpados. (SCHRITZMEYER, 2004, p. 138)

O regime instituído pela Constituição de 1946 não prevaleceu ante ao golpe de Estado orquestrado pelas Forças Armadas e por setores conservadores da sociedade civil. Os anos de ditadura foram marcados por inúmeras perseguições, torturas, violência contra opositores ao regime, além de graves violações aos tratados internacionais de proteção aos direitos humanos. Importante destacar a posição oficial da hierarquia episcopal católica quando da instauração da ditadura.

Orientada por seu atávico anticomunismo, por seu tradicional adesismo ao Estado e por seus interesses institucionais, o episcopado católico manifesta oficialmente seu apoio ao golpe militar de 1964. O manifesto emitido pela CNBB, dois meses após o golpe, agradece aos militares e rende 'graças a Deus' por eles terem acudido o angustiado 'Povo Brasileiro' e defendido os 'supremos interesses da Nação' evitando que 'se consumasse a implantação do regime bolchevista em nossa Terra'. A libertação militar do povo e da nação brasileiros do 'perigo comunista', a seu ver, fora conduzida nada menos que pela própria 'Proteção Divina', que, nesse episódio, 'se fez sentir de maneira sensível e insofismável’. (MARIANO, 2001, p. 152).

Mesmo que a constituição de 1967 tenha assegurado o livre exercício dos cultos religiosos, é sempre salutar considerar que esta premissa nunca foi uma realidade efetiva no país durante os anos da ditadura militar. Algumas religiões continuavam a sofrer duras perseguições, justificadas, em 
grande medida, pelo exclusivismo religioso da Igreja Católica. ${ }^{3} \mathrm{Na}$ verdade, a constituição de 1967 talvez devesse ser considerada um texto formal, pois o país era governado e instruído normativamente por atos institucionais e diferentes decretos que garantiam o poder absoluto das forças militares (RODRIGUES, 2014, p. 119).

Com a derrocada progressiva do regime militar e a gradativa abertura à democracia e a eleição de um presidente civil, o caminho para a consolidação de uma nova constituição estava delineado. A carta constitucional de 1988 representava a possibilidade de construção de um Estado e uma sociedade com uma efetiva participação popular, com respeito ao pluralismo e à liberdade. Neste sentido, inaugurava-se também o paradigma do Estado Democrático de Direito. Especificamente acerca da liberdade religiosa ocorreu a adoção do princípio de um Estado laico respaldando o respeito à diversidade, ainda que tenha sido feito referência a Deus no preâmbulo. ${ }^{4}$ De acordo com o jurista Fábio Carvalho Leite (2014, p. 309), esta questão pode ser explicada, conforme segue:

[...] herdamos [...] uma doutrina que, embora reconhecesse as restrições de um preâmbulo na interpretação constitucional, sempre fez questão de discorrer longamente sobre a importância da referência à divindade, extraindo daí consequências na maior parte das vezes de uma indisfarçável idiossincrasia.

3 Convém destacar também as interlocuções das Igrejas Luteranas, Presbiterianas e Batistas durante a Ditadura Militar. Não raro, houveram ações em estreita colaboração tanto nos bastidores, ou então, publicamente nos púlpitos, em orações, campanhas e vigílias. De acordo com Rubem Alves (1979), o protestantismo brasileiro neste período soube consolidar uma mentalidade concatenada com práticas autoritárias que se mantiveram encobertas por um discurso democrático e liberal (...). "Fica claro, portanto, que os evangélicos, assim como a Igreja Católica, não somente apoiaram a conspiração que levou o Brasil ao Golpe de 1964, como também, após a sua ocorrência não deixaram de tornar pública a sua satisfação por tal evento. Não houve lamentação pela quebra da ordem democrática, nem quaisquer referências para o custo em atentados aos direitos humanos dos que foram presos, torturados, cassados e exilados. Nada disso era importante. O que se exigia era a restauração da ordem" (CAMPOS, 2014, p.186).

4 "Nós, representantes do povo brasileiro, reunidos em Assembleia Nacional Constituinte para instituir um Estado Democrático, destinado a assegurar o exercício dos direitos sociais e individuais, a liberdade, a segurança, o bem estar, o desenvolvimento, a igualdade e a justiça como valores supremos de uma sociedade fraterna, pluralista e sem preconceitos, fundada na harmonia social e comprometida, na ordem interna e internacional, com a solução pacífica das controvérsias, promulgamos, sob a proteção de Deus, a seguinte CONSTITUIÇÃO DA REPÚBLICA FEDERATIVA DO BRASIL”. 
Como consequência desta posição doutrinária ambígua e indeterminada tem sido frequente [...] a citação desta frase preambular no processo de interpretação constitucional em casos que direta ou tangencialmente envolvem a religião.

Para efeitos de compreensão, a menção a Deus, embora indutora de discussões ou até distintas interpretações, no fundo, acaba sendo desprovida de um sentido jurídico com um caráter mais claro. A manifestação pela invocação e proteção divina encontra algum sentido no aparato simbólico. Afinal, a crença religiosa é, por definição, algo concernente ao âmbito pessoal, podendo abranger uma coletividade, mas, de fato, não há como atribuir tal premissa ao Estado. O reconhecimento, por exemplo, de que a maioria do povo brasileiro é religioso, cristão e católico, é uma constatação sociológica e não uma evidência jurídica (ÁVILA, 2004). Uma análise mais detalhada da própria história constitucional brasileira sempre haverá de se deparar com o fato de que os problemas relacionados à liberdade religiosa e às relações entre Estado e Religião pouco decorrem das normas, mas, de sua interpretação, em geral, em um sentido particular e contingenciada por ambiguidades infraconstitucionais.

Importa reconhecer que o Estado Brasileiro deveria, em tese, garantir a representação e expressão religiosa para todas as pessoas, de todas as confissões e a não adesão a uma determinada fé religiosa se este fosse o caso. Não deveria, pois, priorizar uma manifestação em detrimento da outra, sob pena de estar afetando o direito de minorias e sua própria essência constitucional. Para garantir o tratamento isonômico é que, pelo menos no plano formal, existe a prerrogativa da laicidade mediante a qual o Estado é responsável por atuar de modo a impedir tratamentos discriminatórios, direta ou indiretamente, autonomizando a política e a sociedade civil em relação às normas religiosas e filosóficas particulares, e consagrando o respeito a todas as liberdades, práticas e liturgias, a nível individual ou coletivo (HUACO, 2008, p. 33-80).

Este processo, contudo, nunca ocorreu de forma satisfatória no Brasil. O que se percebe, cada vez mais, é um reiterada ação cotidiana de atos estatais devotados à prática de discriminações e impedimentos à liberdade de expressão por meio da cultura, da arte, bem como, da utilização desregulada de instalações e prédios públicos para realização de cultos e liturgias específicos daqueles que exercem postos estatais de chefia, mas que 
deveriam se concentrar no uso estrito para o serviço público, por não serem bens de uso comum. Não é, pois, uma coincidência e nem um questão menos importante que em muitas ocasiões os símbolos religiosos dominantes estejam lado a lado com o nosso principal símbolo cívico, a bandeira nacional. As narrativas e os símbolos religiosos entabulam uma gramática e um vocabulário capaz de descrever os percursos delineados pela nação em sua complexidade (SARMENTO, 2007, p. 75-90).

O ideário constitucional através da adoção rígida de mecanismos de jurisdição já indica para a rejeição de qualquer concepção que identifique a democracia com o predomínio da vontade de uma pretensa maioria. A proteção constitucional de direitos, ao impor limites para as maiorias, não é incompatível com a democracia, mas, antes, garante os pressupostos necessários para o seu bom funcionamento. Não é por acaso que as democracias mais estáveis são também aquelas em que os direitos fundamentais, inclusive das minorias, são os mais respeitados. O Estado republicano pode não ter oficializado uma premissa religiosa, mas, a sua interlocução sempre foi intensa como, por exemplo, no caso da estreita aproximação de Getúlio Vargas à Igreja Católica com o claro propósito de dar forma a um projeto de unificação nacional. É importante ressaltar que o país nasceu sob a hegemonia cristã e se formou como nação através de uma grande pluralidade cultural e religiosa. O interesse que o Estado tem pela religião existe em decorrência de sua força de legitimação do discurso, do poder da fé que movimenta massas e conquista votos, do caráter aglutinador e de articulação estratégica e do perfil transformador da esfera social (CATROGA, 2006).

A efetividade jurídica deveria garantir e promover no Estado Democrático de Direito não uma pretensa moralidade positiva - que toma os valores majoritariamente vigentes como um dado inalterável, por mais opressivos que sejam - mas uma moralidade crítica. É a moral que não se contenta em chancelar e perpetuar todas as concepções e tradições prevalecentes, endossando um status cultural, mas que propõe alguma reflexão crítica a partir de uma perspectiva que se baseia no reconhecimento da igual dignidade de todos os seres humanos (WEINGARTNER, 2007).

Em resumo, os pressupostos inerentes à laicidade deveriam resguardar a liberdade religiosa e, por extensão, não se confundir com uma religião em particular, mas, propiciar a independência da esfera política e religiosa, que entre si são comunicáveis pelo princípio da autonomia. Cabe ao Estado, pois, 
atuar tanto no sentido de não interferir no âmbito da vivência religiosa dos indivíduos, quanto possibilitar a manifestação destes no espaço público, sendo possível colaborar com confissões religiosas, tratadas de forma equitativa, reconhecendo a relevância do fator religioso para o bem da sociedade com vistas à efetivação da dignidade humana.

Entrementes, com a catástrofe pandêmica do Covid-19 a partir do início de 2020, houve, mais uma vez, uma intensa mobilização e atuação de lideranças religiosas, sobretudo, evangélicas pentecostais e neopentecostais, buscando interferir e modificar o status dos serviços prestados em ambientes e templos religiosos. A suspensão de diversas atividades, dentre elas o funcionamento de cultos, fez soar o ativismo em favor daquilo que se convencionou chamar de "serviço essencial", como ainda veremos adiante. Em geral, o que se vislumbrou foi uma contínua referência a supostos problemas decorrentes do confinamento social engendrado pelos discursos de lideranças religiosas com o propósito de desautorizar decretos de prefeitos e governadores em detrimento daquilo que era defendido pelo presidente da república. Antes disso, vamos nos ater ao amálgama entre religião e sistema econômico que, no contexto brasileiro, em particular, tem sido característico de um certo "modo de ser" evangélico.

\section{Fundamentalismo e capitalismo autoritário no Brasil}

Em Os Múltiplos Altares da Modernidade, Peter Berger chama atenção para a crise do paradigma da secularização mediante a explosão religiosa no mundo contemporâneo, especialmente no que ele chama de Sul Global. O autor destaca a emergência do pentecostalismo e do islamismo como dois movimentos religiosos que se notabilizaram, nas últimas décadas, pela militância com que procuram intervir e ordenar uma esfera pública cada vez mais plural e ameaçadora à antiga norma do "mundo-dado-como-certo" (BERGER, 2017, p. 69).

Nesse contexto, é que o termo fundamentalismo ${ }^{5}$ ganha uma presença constante no debate público, sendo sempre acionado pelos críticos e

\footnotetext{
Uma excelente exposição sobre o termo é feita por Magali Cunha (2020, p. 4): “A origem do termo remonta à tendência ultraconservadora de um segmento protestante dos Estados Unidos, na virada do século 19 para o 20, enraizado na interpretação literal da Bíblia, classificada como inerrante, em reação à modernidade, (encarnada na teologia liberal e no estudo bíblico contextual com mediação das ciências humanas e sociais), em defesa dos fundamentos imutáveis da fé cristã. De lá para cá, a perspectiva fundamentalista foi se transformando, no interior do evangelicalismo mesmo, e ultrapassou as fronteiras da religião. Torna-se uma matriz de pensamento, uma postura, ancorada [na] defesa de uma verdade e na imposição dela à sociedade".
} 
opositores desses movimentos para expressar o que consideram uma intervenção indevida da religião na gestão do estado e da sociedade. Não nos cabe aqui discorrer sobre os usos ou abusos ${ }^{6}$ do conceito de fundamentalismo, ainda que isso seja necessário. O que importa para nossos objetivos, é a reflexão feita por Berger (2017, p. 74) sobre o fundamentalismo e suas exigências políticas "totalitárias":

O fundamentalismo pode ser descrito como um projeto de eliminação total da dúvida. Pode também ser descrito como uma tentativa de restaurar, nas condições modernas, a certeza do dado-como-certo de uma sociedade prémoderna. Isto é difícil de fazer, pois exige ou um regime totalitário que controla toda uma sociedade, o que representa altos custos econômicos e outros custos, ou o minitotalitarismo de uma subcultura sectária, que exige constante vigilância contra as contaminações cognitivas que vem do exterior.

O que o autor evidencia é que uma subcultura religiosa fundamentalista, cujo objetivo seja impor seus padrões de comportamento à sociedade, tende a desejar um regime político autoritário, desde que seja seu aliado, como um meio para tornar seu projeto factível. Assim, ele nos possibilita pensar a simbiose existente entre fundamentalismos religiosos e estados autoritários que assistimos amiúde no mundo contemporâneo. Mas o autor aponta também os custos econômicos, além de outros, que podem estar implicados nessa relação. Tal consideração nos leva a questionar sobre os aspectos econômicos do fundamentalismo: o quanto ele pode ser contraditório ou favorável aos interesses econômicos?

Os custos econômicos do fundamentalismo, como suscitado por Peter Berger, reforça um sentido de oposição, uma sensação despertada em nós quando pomos lado a lado, os termos fundamentalismo e capitalismo. Para nos limitarmos apenas ao cristianismo, vale trazer como exemplo as ordenações de Igrejas mais aferradas a padrões de comportamento, muitas vezes, pressionando seus adeptos a uma interdição ao livre consumo seja da cultura, da moda, da ciência, designando tais bens (materiais e simbólicos) como perigosos demais para a convicção e o bom testemunho dos seus fiéis. ${ }^{7}$

6 Pesquisadores tem chamado atenção para um uso indevido do termo, seja na mídia, nas lutas políticas e mesmo nas ciências sociais, cujo discurso, muitas vezes, parece mais ter o objetivo de estigmatizar certas expressões ou grupos religiosos do que ensejar a compreensão analítica do fenômeno religioso em pauta, especialmente quando se trata de intervenções desses grupos religiosos no espaço público (ORO, 1996).

7 No Brasil, o chamado pentecostalismo clássico (Assembleias de Deus e Congregação Cristã do Brasil) expressou, historicamente, a adoção de restrições mais rígidas sobre os chamados "usos e costumes" (cf. FRESTON, 1993; MARIANO, 2005.) 
Se é possível apontar para algumas oposições entre os fundamentalismos e o capitalismo, ${ }^{8}$ evidentemente suas relações não se esgotam nas contradições e, nesse sentido, o Brasil dos tempos pandêmicos tem se mostrado uma expressão notável da complexidade dessa articulação. Assim, para os observadores atentos, não é casual a inquietante semelhança entre o discurso de que "a economia não pode parar" por causa da pandemia (refletindo claramente o interesse dos empresários) e o discurso emitido por alguns líderes religiosos - sabidamente por pastores evangélicos midiáticos, reconhecidos mesmos como "empresários da fé" -, de que "o culto não pode parar", o que para os críticos mais mordazes dessas personalidades significa, na verdade: "a arrecadação não pode parar!” (ALMEIDA; GUERREIRO, 2020).

A partir dessa realidade e das inquietações que ela nos provoca, servimo-nos do conceito weberiano de afinidades eletivas para pensar essa complexa relação entre fundamentalismo e capitalismo no Brasil. As "afinidades eletivas" são os pontos de contato e apropriação mútua existentes entre processos culturais e sociais distintos, que se estabelecem, ainda que não intencionalmente, por meio de seus agentes, servindo à ampliação e consolidação desses processos históricos (WEBER, 2004).

Em outras palavras, quando determinado comportamento, desde que compatível aos dois sistemas em relação, passa a ser estimulado por ambos para que os indivíduos o adotem (ainda que por motivações distintas), este padrão comportamental torna-se mais convincente ou até mesmo naturalizado, não parecendo aos indivíduos como uma imposição externa, mas, sim, como uma autodisciplina. É nesse ponto que, seguindo as trilhas abertas por Weber (2004), podemos dizer que a religião é uma fonte moral não negligenciável para os propósitos de manutenção dos sistemas econômicos e políticos.

Do ponto de vista histórico, a relação entre fundamentalismo e capitalismo no Brasil começa a ser elucidada. Os historiadores Lyndon Santos e Adroaldo Almeida (2014) esclarecem não ser mera coincidência cronológica que a expansão fundamentalista nas Igrejas evangélicas brasileiras ocorre justamente no contexto da Guerra-Fria e do macartismo (caça aos comunistas), nas décadas de 1950/1960. Nesse sentido, a influência

\footnotetext{
8 Se, de um lado, em algumas crenças e práticas, o fundamentalismo cristão parece ser contraditório ao capitalismo, isso não exclui o fato de que, na totalidade de sua presença histórica no ocidente, como veremos adiante, ele esteja ideológica e institucionalmente vinculado à defesa do sistema capitalista. Basta lembrar que na sua origem, quando surgiu na virada do século XIX para o XX, elegeu como um dos seus inimigos a Teologia do Evangelho Social, esse de postura crítica às estruturas capitalistas.
} 
imperialista/macartista expressou-se, no interior do campo evangélico, principalmente por meio do estabelecimento de instituições eclesiásticas e para-eclesiásticas norte-americanas, alinhadas com uma interpretação teológica de inspiração fundamentalista/intolerante/racista. Estas instituições contribuíram para ressignificar bandeiras dos evangélicos fundamentalistas brasileiros, especialmente acirrando um combate implacável ao comunismo e aos considerados "comunistas" ainda que estes fossem seus irmãos de fé, gerando expurgos internos e entregando-os à prisão e tortura da ditadura instalada em 1964.

A partir dessa histórica relação, é necessário agora voltar nosso olhar para o presente e nos perguntarmos: como ocorre a relação entre o fundamentalismo e o capitalismo no Brasil dos tempos pandêmicos? Ou seja, nos perguntamos sobre as lógicas inerentes à semelhança entre o "deixa eu abrir minha lojinha" e o "deixa eu abrir minha igrejinha". Esta similitude, a nosso ver, evidencia os pontos de contato entre a mentalidade capitalista que considera a manutenção do negócio acima das preocupações com a vida dos trabalhadores e trabalhadoras e um tipo de vivência religiosa que considera como central à manutenção da fé, a presença coletiva no templo de culto, ainda que pondo sob risco a vida dos fiéis.

Essa relação entre fundamentalismo e capitalismo - que chega ao ponto de não se importar com perda de vidas em nome da reprodução do capital ou em nome da reprodução da instituição eclesiástica, na sua manutenção econômica e de poder sobre os fiéis -, fica melhor esclarecida se considerarmos o tipo de capitalismo desenvolvido no Brasil e que se manifesta de maneira mais explícita naqueles espaços geo-sócio-culturais que a teoria pós-colonial tem chamado de fronteira, na verdade, nas diferentes fronteiras do sistema-mundo capitalista (WALLERSTEIN, 1999).

Nesse sentido, para pensar a relação entre fundamentalismo e capitalismo, tal como temos observado nesses episódios recentes, pareceunos útil retomar a categoria de "capitalismo autoritário" do sociólogo Otávio Guilherme Velho (2009). Esse capitalismo autoritário, para Otávio Velho, é o que caracteriza um tipo de capitalismo empreendido nas frentes de expansão da exploração econômica, especialmente sobre as franjas da floresta amazônica nos estados do Maranhão, Pará, Tocantins e Mato Grosso, onde ele realizou suas pesquisas de campo no começo dos anos 1970.

Segundo o sociólogo: “o capitalismo autoritário - ou mais rigorosamente, o capitalismo com dominância autoritária - é o herdeiro 
direto de sistemas de repressão da força de trabalho sem nenhum corte revolucionário interveniente" (VELHO, 2009, p. 35). Ou seja, é um capitalismo ${ }^{9}$ com articulação e manutenção das formas não capitalistas de exploração do trabalho e, acrescentaríamos, de grande exploração dos recursos naturais.

Essa exploração econômica é sempre alardeada pelos discursos estatais e empresariais como expansão capitalista, modernização do campo, desenvolvimento regional, integração territorial etc.; na prática, ela ocorre como exploração econômica intensiva e predatória sobre os recursos naturais e sobre os grupos humanos vinculados a esses territórios e ecossistemas; tudo isso com o beneplácito e apoio logístico, estrutural e jurídico-político dos entes estatais (cujo símbolo notório da cumplicidade estatal é legitimação cartorial de terras roubadas de camponeses tradicionais, a chamada grilagem) (ASSELIN, 2009).

Dessa forma, o capitalismo autoritário é parasitário e predatório dos ecossistemas em que vidas humanas e não-humanas integram-se orgânica e culturalmente. Esse parasitismo não se dá pela ausência do estado ou falta de controle fiscal/governamental, como muitos pensam e dizem (vide as queimadas na Amazônia e do Pantanal, acompanhadas do desleixo zombeteiro do atual governo, (CATRACA LIVRE, 2020). Pelo contrário, ele acontece exatamente pela ação, cumplicidade e conivência do estado com os agentes capitalistas, sejam eles grileiros e especuladores de terras, madeireiros, latifundiários do gado e da soja, empresas multinacionais de mineração; isso sem esquecermos aqui dos chamados grandes projetos de infraestrutura capitaneados pelo estado desde os tempos da ditadura, como a construção de várias hidrelétricas ao longo dos leitos dos rios amazônicos - devastando ecossistemas e espoliando populações, expulsando-as de suas casas e territórios no qual, de longa data, possuíam o seu bem "con-viver" (VELHO, 1999; MARTINS, 2019).

Esse capitalismo autoritário das fronteiras amazônicas é, parafraseando José de Souza Martins, um capitalismo que desumaniza o outro - aquele que está do outro lado da fronteira da modernização; esse outro é desumanizado

\footnotetext{
9 Apesar da crítica de José de Souza Martins, de que esse "capitalismo autoritário" é o próprio "capitalismo burguês", pois não é "possível outro capitalismo que não o burguês" (2019, p. 73), adotamos o conceito não como oposição a um capitalismo liberal típico-ideal, mas como um esforço em deixar claro a violência embutida, e legitimada pelo estado, nesses processos de acumulação do capital nas regiões de fronteira.
} 
para que a vida dele seja dispensável, matável: "nesse sentido, a fronteira tem um caráter litúrgico e sacrificial, por que nela o outro é degradado para, desse modo, viabilizar a existência de quem o domina, subjuga e explora" (MARTINS, 2019, p. 11).

Matáveis são camponeses, posseiros, indígenas, quilombolas, comunidades e povos tradicionais. Concretamente, são corpos de homens e mulheres que, caso tentem resistir, são vistos por estes poderes econômicopolíticos como uma barreira ou estorvo ao processo de modernização, tornando-se aceitável e, em última instância, legítimo (já que os agentes estatais, quando não são eles próprios atores e cúmplices, são coniventes com tais assassinatos $^{10}$, que essas vidas sejam sacrificadas no altar da modernidade ${ }^{11}$, para que a expansão capitalista continue acumulando riquezas nas mãos daqueles poucos citados acima - um verdadeiro sacrifício ao deus Mamon ${ }^{12}$.

Dessa forma, cabe a pergunta: se essa mentalidade e lógica do capitalismo autoritário não é a mesma que subjaz a insistência de alguns padres e pastores evangélicos em reabrir as igrejas, ainda que no

10 Não são raros os casos de assassinatos de lideranças camponesas e/ou indígenas, na qual interesses econômicos e agentes públicos estiveram comprovadamente associados, chegando a serem condenados. Um caso emblemático e de repercussão nacional foi o do assassinato do Padre Josimo em 1986, em Imperatriz-MA (MST, 2010), onde se associaram, um pistoleiro, fazendeiros da região e um vereador do município de Augustinópolis-TO. Uma ação do Governo do Estado do Maranhão que ficou conhecida pela sua violência indiscriminada em nome do combate ao crime, nos anos 1990, foi a famigerada "Operação Tigre", que acabou sendo uma oportunidade para se eliminar eventuais inimigos de políticos, fazendeiros e de outros interesses econômicos na região (MENDES, 2016, p. 39-66).

11 Tal concepção do capitalismo autoritário guarda uma similaridade com o conceito de necropolítica (MBEMBE, 2016), o que não é casual, devido a ambos surgirem da mesma condição colonial: a de expansão do poder político externo e da exploração econômica sobre os espaços e suas populações. O termo necropolítica, por sua vez, tem sido bastante utilizado no debate contemporâneo para caracterizar uma ação/omissão genocida do estado, seja diretamente por meio ação das forças de segurança contra uma parte da população considerada perigosa à nacionalidade, seja pela ausência de política pública e estruturas de saúde, educação e segurança que garantam suas vidas, reduzindo, ao máximo, suas condições de sobrevivência.

12 Embora seja bastante frutífera a tese do "Capitalismo como Religião" levantada por alguns teólogos, cientistas da religião e sociólogos contemporâneos - a fim de possibilitar uma crítica radical aos valores e crenças que dão sustentação simbólica às bases materiais do sistema capitalista (COELHO; SUNG, 2019) -, a abordagem desenvolvida neste artigo, da relação entre fundamentalismo e capitalismo, distingue-se dela, em razão do pressuposto, adotado aqui, de que religião e economia são sistema externos e autônomos, um em relação ao outro, mas com influências mútuas em condições históricas específicas, como se depreende do próprio conceito de "afinidades eletivas" operacionalizado nesta análise. 
auge da pandemia? Não se manifesta aqui uma afinidade eletiva desse fundamentalismo com o capitalismo autoritário brasileiro? Um capitalismo que torna descartável vidas fronteiriças, vidas negras, indígenas, de homens e mulheres não brancos, conviventes nas periferias do sistema-mundo, esteja tal periferia no campo ou nos grandes centros urbanos do país; sendo tais genocídios avalizados e estruturados pelo próprio estado, esse, cada vez mais, cooptado e dominado pela lógica de mercado.

Esta é a cara do nosso capitalismo autoritário, como o define Otávio Velho: onde o estado é agente e cúmplice dos interesses privados mais predatórios e assassinos, a fim de que o business não seja estancado, onde o corpo do outro (preto, pobre, periférico), é só mais um recurso/instrumento para ser consumido e usado na manutenção ou expansão do negócio, mas que jamais deve se configurar como um limite ou uma interdição ao empreendimento - seja tal empreendimento uma multinacional da mineração na Amazônia ou uma "multinacional da fé", instalada nos centros urbanos.

Compreender esse capitalismo autoritário não exclui entender que as lógicas dessa exploração possam ser tomadas pelos sujeitos que são vítimas dela como se fossem as suas próprias lógicas. Essa internalização subjetiva de um interesse externo (a lógica do sistema econômico) é a principal razão da associação entre uma ética econômica que se quer dominante e uma ética religiosa, algo que Weber a muito nos ensina.

Trazendo isso para o nosso tema religioso, o fato dos próprios fiéis desejarem voltar a frequentar os cultos ou mesmo simples pastores e padres das periferias e recantos do país também defenderem a abertura de seus templos, crendo assim fazer um benefício à fé das pessoas, não exclui o fato dessas inclinações psicológicas e de fé estarem ancoradas e servirem a uma lógica econômica exploratória dos corpos e da fé das pessoas, ainda que elas não se deem conta disso, crendo que seus discursos e ações são somente um dever moral consigo, com seus fiéis e com sua divindade.

Em outras palavras, ainda que adeptos e alguns agentes religiosos apenas estejam movidos pelas suas necessidades de fé (de frequentar ou realizar os ritos públicos), isso não pode obscurecer a compreensão de que, na conjuntura de uma emergência de saúde pública, essa prática reproduz uma lógica econômica que em última instância é contrária ao senso de humanidade, quando não aos postulados da própria fé que se diz defender. Ter consciência disso, dessas lógicas desumanizadoras que estão no substrato desses discursos e práticas religiosas (e que são facilmente naturalizadas), 
é um passo fundamental para a busca de alternativas à vivência da fé em tempos de pandemia.

\section{Pretensões de sentido e verdade na argumentação pública da relevância da abertura de templos religiosos em meio a pandemia do Covid-19}

Feita uma apresentação panorâmica de aspectos concernentes a liberdade religiosa no contexto brasileiro, bem como, da profunda relação entre capitalismo e religião, cabe agora um olhar para um evento que pode ajudar a ilustrar a discussão aqui ensejada.

Este estudo de caso analisa uma campanha midiática realizada pela TV Record em favor da abertura de templos religiosos em meio à pandemia da Covid-19. Entre os dias 27 de julho e 2 de agosto de 2020, a emissora dedicou ao tema quase duas horas de programação distribuídas entre o Jornal da Record $(\mathrm{JR})^{13}$ - com reportagens de segunda à sexta -, a Live JR e o programa Domingo Espetacular. No presente momento nos atemos às cinco reportagens que foram ao ar no JR entre os dias 27 e 31 de julho. Neste tópico, portanto, objetiva-se apresentar os principais aspectos da narrativa criada, bem como, apontar algumas fragilidades ou limites na argumentação entabulada.

Os títulos e descrições dos vídeos das reportagens na conta oficial do JR no Youtube são sugestivos. Cabe indicar que as descrições dos vídeos são baseadas em falas presentes nas reportagens, e, em grande parte, elas já compõem a chamada lida pelos apresentadores do telejornal na introdução à cada matéria:

Prefeitos impedem ida a templos e igrejas (Segunda-feira, 27 de julho):

A ciência comprova: a fé é um aliado importante para a saúde do corpo e da mente. Mas, na pandemia, decretos municipais e estaduais proibiram a abertura de templos e também de igrejas. No Paraná, um culto foi denunciado mesmo respeitando normas e evitando aglomerações.

Fechamento de templos e igrejas prejudica ações sociais durante a pandemia (Terça-feira, 28 de julho):

13 Na internet, no Canal do JR no YouTube, é possível ter acesso aos programas completos do JR, bem como, aos vídeos separados de cada reportagem. 
As igrejas e templos religiosos exercem uma função social importante no país. Além de doar alimentos, kits de higiene e roupas, oferecem também apoio psicológico e emocional. Na pandemia, a demanda por essas ações voluntárias ficou ainda mais evidente. Porém, mais de 500 cidades brasileiras ainda pró́bem a abertura de espaços religiosos, o que prejudica a ajuda à população.

Na maior crise do século, fé é aliada importante para a saude do corpo e da mente (Quarta-feira, 29 de julho):

A abertura de templos e igrejas é considerado serviço essencial há quatro meses pelo presidente da República. Mesmo assim, centenas de prefeitos mantiveram fechados estabelecimentos religiosos. Como se não bastassem os tantos problemas causados pela pandemia, vieram as incertezas, o medo. Distúrbios como ansiedade e depressão aumentaram e, em muitos casos, levando até ao suicídio. Nesse momento, a fé é um aliado importante para a saúde do corpo e da mente.

Fechamento de templos e igrejas pode ter impacto nas eleições municipais deste ano (Quinta-feira, 30 de julho):

Igrejas e templos também tiveram que se adaptar à realidade imposta pela pandemia. Todos os cuidados foram tomados para dar segurança aos fiéis. Mesmo seguindo os protocolos, quase 400 prefeituras não respeitaram o decreto federal que considerou as atividades religiosas um serviço essencial. A decisão, segundo cientistas políticos, pode custar caro nas próximas eleições municipais.

Maioria dos brasileiros é a favor da abertura dos espaços religiosos, aponta pesquisa (Sexta-feira, 31 de julho):

Não tem sido fácil para o brasileiro, um povo tão apegado a fé, se deparar com os templos fechados. Uma pesquisa do Instituto Real Time Big Data divulgada nesta quinta-feira (30) ouviu pessoas de todas as regiões do país sobre igrejas e o isolamento social. Quando perguntadas sobre a situação dos espaços religiosos na pandemia, 61\% disseram ser a favor da abertura. No momento, 336 prefeituras do país mantêm os locais interditados, desobedecendo um decreto federal que considerou as atividades religiosas um serviço essencial à sociedade. 
O problema enfrentado pelo editorial é a não abertura de templos em centenas de cidades brasileiras ${ }^{14}$. O tema é tratado como algo de volume bastante representativo. Entretanto, segundo dados do IBGE (2017), o país conta hoje com cerca de 5.570 municípios. Ao se tomar o dado da sextafeira, dia 31 de julho, em que se apresenta um número preciso de cidades que impedem o funcionamento de templos, a saber, 336. A porcentagem de municípios que até o momento da campanha não havia adotado a flexibilização seria de pouco mais de $6 \%$. Ao se considerar o dado das mais de 500 cidades citadas na segunda-feira, ainda assim, não se chegaria a $10 \%$ do total de municípios brasileiros. As reportagens até apresentam dados populacionais, mas não de modo a se possibilitar um cálculo da porcentagem da população que vive nessas cidades. O que se percebe no decorrer da semana é o incômodo com cidades que possuem centenas de milhares de habitantes como Blumenau e Juiz de Fora, além de uma capital como Porto Alegre que conta com cerca de 1,4 milhão de habitantes, segundo dados do JR. Parece-nos oportuno apontar que a premissa das reportagens está equivocada, uma vez que a grande maioria das cidades, durante o mês de julho, já havia liberado as atividades religiosas, ainda que com restrições. $\mathrm{O}$ que poderia motivar essa campanha midiática? Haveria ligação com a queda de arrecadação das igrejas em cidades populosas? (NASCIMENTO, 2020; DIP et al., 2020) Há um ímpeto de cuidado pastoral que encontra limitações reais em virtude da limitação das práticas de culto?

De qualquer modo, nota-se uma motivação para a flexibilização das atividades nos templos que dá sentido às reportagens. Para justificar a necessidade ou viabilidade dessa reabertura a narrativa de sentido elaborada pela Rede Record se baseia nas seguintes linhas de argumentação: 1. O decreto federal que coloca os serviços religiosos como atividade essencial em contraposição às atitudes de governadores e prefeitos que não liberam o funcionamento dos templos; 2. A fé é de grande relevância para a população (não só de igrejas cristãs, mas, também, de outras expressões de fé) e sua prática tem sido limitada no contexto da pandemia pela ação de estados e prefeituras; 3. O apoio popular à abertura dos templos; 4. As igrejas cumprem os devidos protocolos de higiene; 5 . O descontentamento de fiéis e lideranças

\footnotetext{
14 Segundo informações do próprio JR, seriam cerca de quinhentas cidades (dados da segunda-feira) que até o término da semana já estava na casa das 336 prefeituras. Se os dados estiverem corretos, as reportagens conseguiram reverter a situação em mais de cem cidades em apenas uma semana.
} 
religiosas com a postura de prefeitos e governadores pode ter reflexo nas urnas; 6. A relação entre fé (espiritualidade) e saúde embasada na ciência, bem como o apoio emocional e espiritual das igrejas no combate à ansiedade e depressão (igrejas como hospitais espirituais); 7. A relevância das ações sociais das igrejas que seriam prejudicadas pelo fechamento dos templos; 8. As igrejas como local de refúgio para mulheres que sofrem violência doméstica.

1. O Decreto $n^{\circ} 10.292$, de 25 de março de 2020, do governo federal, elenca as "atividades religiosas de qualquer natureza, obedecidas as determinações do Ministério da Saúde" como atividades essenciais. Essa é a base legal à qual o JR apela para dar legitimidade à sua campanha. Nota-se que não é feita qualquer ressalva em relação ao decreto, não se entrevista, por exemplo, nenhum sanitarista ou jurista para questionar a pertinência do item que diz respeito às atividades religiosas. A sentença é assumida como base sólida de argumentação sem maiores ressalvas. Recorre-se insistentemente ao texto, em geral, para se provar um ponto de validade da narrativa, bem como, para marcar a tensão entre gestão federal, de um lado, e administrações municipais e estaduais de outro. Não raro, se passa a ideia de que prefeitos e governadores impedem o funcionamento das igrejas e limitam a prática de fé dos fiéis. Inclusive, engendra-se a noção de que a desassistência espiritual, emocional e espiritual da população se origina no desrespeito de prefeitos e governadores ao decreto federal.

2. Outra linha de argumentação, acessada em todas as reportagens, é a importância da fé para os brasileiros. O JR se utiliza de dados do IBGE que indicam que a grande maioria da população, no caso, 92\%, está ligada a alguma religião. Nesse sentido, a própria construção do raciocínio não se limita ao âmbito evangélico, ou mesmo cristão. Pessoas ligadas ao islamismo, judaísmo, espiritismo e religiões de matriz afro-diaspóricas são consultadas para discorrer acerca da importância da fé para a vida das pessoas. Diz-se que Igrejas e religiões são afetadas pela proibição dos encontros presenciais.

$\mathrm{Na}$ reportagem da segunda-feira, dia 27 , entrevista-se um rabino, David Weitman, um padre, Juarez de Castro, uma mãe de santo, Jaciara Silva Ferreira, e um líder evangélico, apóstolo Estevam Hernandes (Igreja Renascer em Cristo). O assim denominado apóstolo tem a última fala da reportagem em que diz: "Sem fé é impossível agradar a Deus" - ao se considerar a possibilidade de um público cristão, sobretudo evangélico, a sentença de que sem fé não se pode agradar a Deus, pode dar a entender que a não abertura dos templos prejudica o fiel em seu relacionamento com a divindade. 
Eduardo Bravo, bispo da IURD, é apresentado como presidente da União Nacional das Igrejas e Pastores Evangélicos (UNIGREJAS) que, segundo dados da reportagem, representa cerca de 50 mil pastores. Como se poderia esperar, a fala do funcionário da Igreja ligada à Rede Record corrobora a narrativa em curso, defendendo a reabertura dos templos. Ele elogia os prefeitos que permitiram as atividades religiosas, pois, segundo ele, possuem nas igrejas um apoio no cuidado da população. Afirma que os prefeitos que não flexibilizaram as diretrizes em relação ao funcionamento das igrejas, provavelmente, devem ser mal assessorados, não quiseram entender a importância das igrejas ou possuem preconceitos contra elas. À distinção de prefeitos e governadores, apresenta-se o apoio de membros do legislativo federal à liberação das atividades religiosas, todos eles ligados à Frente Parlamentar Evangélica. Recorre-se, inclusive, à noção de Estado laico, trazendo uma fala do jurista Ives Gandra Martins para sustentar a ideia de que a laicidade não é idêntica à um Estado ateu, mas que respeita as religiões.

3. Na mesma linha do destaque da relevância da fé para a população, segue a argumentação do apoio popular à abertura dos templos, o que é suportado por uma pesquisa encomendada pela Rede Record ao Instituto Real Time Big Data. Nas reportagens, entrevistam-se pessoas simples com um linguajar popular. Mostra-se pessoas fazendo vídeos caseiros (de celular) relatando o retorno de atividades de comércio, mas, frisando as cidades nas quais os templos religiosos ainda estão impedidos de abrir. Sobretudo, com base na pesquisa encomendada, sustenta-se que a maioria das pessoas é favorável à abertura dos templos durante a pandemia

4. Com base no texto do decreto que determina que as diretrizes do Ministério da Saúde sejam seguidas para a realização das atividades religiosas, a campanha indica que nas cidades em que o funcionamento dos templos está autorizado, os protocolos são cumpridos. Entrevista-se uma infectologista, Rosana Richtman, que fala da possibilidade de abertura dos templos desde que se respeitem regras como manter o distanciamento social e o uso da máscara. Mostram-se imagens de igrejas com lugares demarcados, e de pessoas participando de um culto mantendo o distanciamento e usando máscaras. O padre Juarez de Castro, da Arquidiocese de São Paulo, diz que as missas são celebradas de forma rápida e se pede que as pessoas saiam logo após o término da celebração e que não façam aglomeração. A reportagem colhe depoimento de uma mulher, para representar aqueles que estão em cidades que permitem a abertura dos templos. Ela fala dos cuidados sanitários 
que são respeitados, inclusive, como direcionamento das próprias igrejas. $\mathrm{Na}$ reportagem do dia seguinte, quinta-feira, enfatiza-se o modo como os templos religiosos se adaptaram para atender aos fiéis durante a pandemia. Mostram-se imagens de outros países e de diferentes confissões religiosas. Fala-se da restrição de $30 \%$ da capacidade máxima, uso de máscara, medição de temperatura nas entradas, uso de álcool em gel. Em mais de um momento se utiliza como contraponto aos templos fechados imagens de bailes funk (pancadão), feiras de rua, transporte coletivo - nos quais o distanciamento social seria desrespeitado. Não se questiona, por exemplo, como os fiéis se locomovem até os templos. Não é inadequado imaginar que fiéis se utilizem do mesmo transporte coletivo superlotado citado na reportagem para conseguirem chegar até as igrejas. Pessoas que, possivelmente, não precisariam utilizar o transporte coletivo caso não pretendessem atender celebrações religiosas. A linha de argumentação ignora a proposta de que, diante de uma doença contagiosa como a Covid-19, se evitem atividades que possam gerar aglomerações.

5. A indignação contra os prefeitos de menos de $10 \%$ dos municípios brasileiros é demonstrada na narrativa das reportagens de modo contínuo. O decreto federal é tomado como base do assim compreendido direito de abertura dos templos. Seguidas vezes as reportagens nomeiam o prefeito de Porto Alegre, Nelson Marchezan Júnior (PMDB) ${ }^{15}$, além de citar outras cidades e prefeitos: Aracaju, Blumenau, Franca, Juazeiro do Norte, Juiz de Fora, Ribeirão Preto, Rio Grande. Não raro, as cidades que mantém restrições às atividades religiosas recebem juízos de valor. Segunda-feira: "outras cidades grandes seguem o mesmo mau exemplo". Quarta-feira: "outras cidades grandes também não respeitam a fé dos cidadãos". Quinta-feira: "mesmo assim, prefeitos de quase quatrocentas cidades brasileiras ainda insistem em contrariar o decreto federal assinado em março que inclui templos como serviço essencial à sociedade"; menciona-se o prefeito de Porto Alegre que "não permite que pessoas que precisam de ajuda espiritual frequentem cerimônias religiosas"; "outras cidades grandes também não respeitam a fé dos cidadãos"; informa-se que em Minas Gerais mais de cem cidades não

15 No sábado, 1 de agosto, o JR apresentou uma reportagem sobre um novo pedido de impeachment, o sexto, contra o prefeito, acusado de utilizar verba em publicidade que seria destinada para a saúde. A prefeitura negou irregularidades. Na mesma reportagem do JR se faz menção à liberação dos jogos de futebol (sem público, vale frisar) enquanto a abertura dos templos seguida impedida. A flexibilização na abertura dos templos em Porto Alegre ocorreu na primeira semana de setembro. O prefeito não foi reeleito em 2020. 
permitiram a reabertura dos templos, nas palavras do narrador "adotaram o mau exemplo"; Sexta-feira: o prefeito de Porto Alegre "liberou a volta do futebol, mas insiste em não permitir que pessoas que necessitam de apoio espiritual, frequentem tempos e igrejas”; “outras cidades importantes também não respeitam a fé dos cidadãos"; “em São Paulo, 104 cidades também adotaram o mau exemplo". Na quinta e na sexta, se dá o endereço do portal R7 (2020) onde se pode encontrar uma lista completa das cidades em que as igrejas estão impedidas de abrir com os nomes dos prefeitos e os caminhos para cobrar deles a reabertura dos templos.

A reportagem, na segunda-feira, destaca o papel da UNIGREJAS, na pessoa de seu presidente, Eduardo Bravo, bispo da IURD, no diálogo com cerca de mil prefeituras para indicar a necessidade de flexibilização das atividades (neste momento a reportagem mostra imagens de pessoas num culto usando máscaras, isto é, cumprindo o que reza o decreto). Bravo reforça a ideia de que a igreja deve ser vista como uma aliada das prefeituras no combate à pandemia. Cabe perguntar se para as prefeituras que não flexibilizassem as restrições em relação às atividades religiosas, essas igrejas representadas pela associação presidida por Bravo se configurariam no oposto de aliadas. Diz o bispo da IURD: "A igreja, ela é a grande aliada do poder público no combate à pandemia. Então, nós apelamos aos prefeitos e governadores, independentemente de partido, deixa o debate democrático para um pouquinho mais tarde e vamos nos unir e ter nas igrejas esse apoio pra ajudar a sociedade que são os que mais precisam".

$\mathrm{Na}$ quarta-feira, apresenta-se um discurso um pouco mais incisivo de Bravo: "Para muitos prefeitos a pandemia foi um trem da alegria, porque aproveitaram as verbas, de comprar sem licitação, superfaturaram os equipamentos pra poder tirar proveito financeiro, mas isso está sendo investigado aí. Então, isso é desumano pra não dizer criminoso". Nota-se que a fala não está relacionada à questão do fechamento dos templos, além de ser apresentada sem fontes. Ela é colocada no contexto de que os maus prefeitos são aqueles que querem as igrejas fechadas.

$\mathrm{Na}$ contraposição entre administração local e federal, apresenta-se de modo contínuo também o suporte de deputados e senadores ligados à Frente Parlamentar Evangélica à abertura dos templos nessas cidades. Entre os parlamentares entrevistados estão: o deputado Silas Câmara ${ }^{16}$

16 Os irmãos Câmara são aliados do governo federal (BLOG DO HIEL LEVY, 2019). 
(REPUBLICANOS/AM), líder da Frente Evangélica no Congresso; Marco Feliciano, deputado federal, (REPUBLICANOS ${ }^{17} / \mathrm{SP}$ ); Izalci Lucas (PSDB/ DF), senador; Vanderlan Cardoso (PSD/GO), senador.

Ainda cabe mencionar o recurso feito ao um cientista político, Pedro Costa, que aponta que esses prefeitos devem ter dificuldades para sua reeleição se insistirem na manutenção dos templos fechados enquanto permitiram a abertura de estabelecimentos análogos; e ao sociólogo Rogério Baptistini que indica ser importante que líderes políticos respeitem o humano como ser de crença e fé.

6. Um dos argumentos que se pretende mais consistente na construção da narrativa do JR é a relação entre fé/espiritualidade e saúde (física e emocional). Esta relação, com amparo científico, está presente em todos os dias da campanha. Menciona-se como fonte um estudo da Duke University em que "pacientes" com fé teriam menos chances de sofrer de depressão. O termo "pacientes" leva a crer que a pesquisa possa fazer parte do contexto de pesquisas sobre espiritualidade e saúde em âmbito hospitalar. Na quarta-feira se repete a informação: "Pacientes que têm fé apresentam 40\% menos chances de sofrerem depressão" (indica-se como fonte a Universidade de Duke, EUA). Os nomes dos autores e ano da publicação não são mencionados ${ }^{18}$. Consultado pela reportagem, Rodrigo Silva, teólogo adventista, corrobora a informação de que há evidências científicas que comprovem a importância da fé e da espiritualidade para a saúde mental e emocional das pessoas novamente a reportagem não apresenta referências mais precisas. A campanha desenvolve uma narrativa que afirma a base científica da relação entre fé e saúde, apresenta a informação de que, com a pandemia, ansiedade, depressão e suicídios teriam aumentado (sem citar fontes); recorre a profissionais ligados ao campo da psicologia: a psicoterapeuta Pollyana Esteves, a psicóloga Sara Rosana Souza Queiroz ${ }^{19}$ e a psicanalista Valéria Amódio; bem como lança mão do testemunho de alguém que, não fosse o refúgio e cura encontrados na igreja, poderia ter cometido suicídio, a vendedora Cássia das Chagas.

\footnotetext{
17 Cabe mencionar que este partido é ligado à IURD (CUNHA, 2018) e, hoje, conta com Carlos Bolsonaro como filiado (MELLO, 2020).

18 Em reportagem do Correio Braziliense, de 2010, apresentam-se dados bastante semelhantes aos mencionados pela reportagem da Record. Nesta reportagem se apresentam os estudos do Prof. Dr. Harold Koenig, referência nos estudos sobre religião/espiritualidade e saúde. Neste e em outros casos, as pesquisas estão comumente direcionadas ao ambiente hospitalar.

19 Que em notícia vinculada pelo site da IURD é descrita como membro da Assembleia de Deus Vitória em Cristo, presidida por Silas Malafaia (UNIVERSAL, 2020).
} 
Assim, cria-se a imagem de que o fechamento dos templos é responsável por uma desassistência emocional e espiritual dos indivíduos. "A pessoa não pode chegar no hospital, o hospital não pode estar fechado e a pessoa não pode chegar na igreja e a igreja não pode estar fechada", afirma Eduardo Bravo. Na mesma direção, o Pastor Adilson Brandão, presidente da Associação Batista Missionária Suleste, diz: “A igreja é um hospital, ela vai continuar sendo um hospital, sempre foi, né, para alguns, até uma UTI. E aí, nós precisamos entender esse contexto em que vivemos, principalmente num país como o Brasil". Na quarta-feira, o mesmo pastor diz o seguinte: "Eles deveriam comparar as instituições religiosas com os hospitais. Porque nós atendemos também pessoas doentes, doentes psicologicamente, espiritualmente, ainda mais com o reflexo dessa pandemia. Então é um tremendo equívoco. Nós não estamos aqui para proporcionar entretenimento, nós estamos aqui para cuidar de vidas". Na sexta-feira, o último vídeo da campanha do JR termina com a seguinte fala de Estevam Hernandes, apóstolo da Igreja Renascer em Cristo: "As igrejas e todos os locais de busca espiritual precisam estar abertos como atividades essenciais".

A reportagem apela à dificuldade de acesso à apoio psicológico para grande parte da população em virtude da renda e do custo desse serviço. Em momento algum, a reportagem cita, por exemplo, que é possível obter atendimento psicológico pelo SUS. Há, portanto, a sugestão de que as igrejas ocupam, inclusive, um vazio de atendimento público.

7. Na terça-feira, de modo mais destacado, a campanha aponta para a relevância das ações sociais das igrejas e, sem indicar fontes, sustenta que estas atividades seriam prejudicadas pelo fechamento dos templos. Afirmase que a pandemia evidencia a necessidade do voluntariado praticado nas igrejas nos âmbitos mencionados. Reforça-se a culpabilização dos governos municipais em não permitirem, dentro dessa narrativa, que as pessoas tenham acesso a apoio social, psicológico e emocional. A reportagem se inicia em tom ufanista acerca da atuação social de uma denominação (Igreja Renascer em Cristo), a música de fundo e as centenas de cestas básicas espalhadas pelo chão ajudam a criar o clima. Cita-se que só naquele final de semana as igrejas teriam mobilizado cerca de 800 toneladas em todo país (não fica claro de onde vem esse número, se está ligado à ação social da Renascer em Cristo, especificamente, ou se houve um levantamento de um grupo de igrejas). Se mostram imagens de uma dessas ações de distribuição de cestas básicas em que, Vladimir Romera, bispo da Igreja Renascer em Cristo, fala 
aos que são contemplados com os alimentos que é por meio daquela cesta que a igreja está chegando na casa delas. Mostram-se pessoas muito simples, em situação de vulnerabilidade social. Fala-se da situação das famílias em que os adultos estão sem emprego. Se mostram os voluntários que entregam as doações orando pelas pessoas da localidade. Uma mãe que recebe o auxílio é entrevistada e diz o seguinte: "A igreja, o propósito dela é mostrar que Deus existe. Então, Deus, você confiando em Deus, você tem a certeza de que nada vai faltar na sua casa e a igreja vem ajudando, mostrando que Deus existe e ajudando a gente com uma cesta ainda". O repórter mostra a cesta, fala da quantidade de alimentos que está dentro dela e do trabalho envolvido nessa ação social. Outra beneficiária da ação social é entrevistada dentro de sua casa, ela testemunha, com a cesta recebida sobre a mesa, que o que a sustenta nesse tempo difícil de ter que ficar em casa é a fé.

Após esta introdução sobre a importância da ação social das igrejas, apresenta-se, em contraposição, o fechamento dos templos - dando a entender que a não possibilidade de atividades religiosas nos templos afetaria o trabalho social das igrejas. Eduardo Bravo, nesse contexto, sustenta que o pedido de flexibilização dos cultos e atividades religiosas tem a ver com a grande contribuição que as igrejas oferecem à população, fala-se dos seus trabalhos sociais e se diz que "muitos desses trabalhos foram afetados pelo fechamento das igrejas", mesmo sem se referir como o trabalho social pode ter sido afetado em virtude da não organização de cultos. Ao fim desta reportagem se mostra novamente a família que foi atendida pelas doações da Igreja Renascer em Cristo. Se diz que esta família está mais tranquila em virtude desse apoio e de que a fé é importante para eles.

8. De modo menos insistente, mas, ainda assim presente, se adiciona à narrativa construída pelo JR a afirmação de que as igrejas são espaços de refúgio para mulheres que sofrem violência doméstica. "Então nós temos trabalhos com mulheres agredidas, esse trabalho não pode parar, nós temos trabalho da igreja dando apoio até às pessoas idosas, esse trabalho foi muito atrapalhado". Nem o funcionário da IURD, nem a reportagem apresentam fontes que suportem essas informações. Bravo continua: "As igrejas intensificaram os atendimentos por telefone, tem recebido muito telefonema, mas há pessoas que nós vemos a necessidade de um atendimento pessoal". $\mathrm{Na}$ quinta-feira, reforça-se esta linha de argumentação ao se denominar as igrejas como locais de socorro de mulheres que sofrem violência doméstica. Sem citar fontes, a reportagem diz que as estatísticas mostram um aumento nos 
casos de violência doméstica. Nesse contexto mostra-se uma fala de Patrícia Alonso, apresentada como especialista em violência doméstica. Ela sustenta que a igreja é o "único lugar" em que a mulher pode encontrar socorro. A argumentação desconsidera os casos em que lideranças religiosas não apenas não socorrem mulheres vítimas de violência, como, por vezes, acobertam ou mesmo são responsáveis por abusos (cf. SOUZA; OSHIRO, 2018; RIGALI, 2007; JURKEWICZ, 2006).

Como resultado desse estudo de caso, há que se reconhecer uma conexão entre sentido e afetos. As reportagens partem de uma necessidade de pessoas reais e concretas em sua falta com relação às práticas religiosas na comunidade de fé onde pertencem ou participam. Não se pode esquecer que nas bases dessas igrejas sempre existem pessoas que exercem naqueles espaços sua relação com o divino; e que estão realmente sofrendo em virtude das limitações às práticas de fé. Contudo, nota-se que, o principal problema tratado pela campanha midiática foi o fechamento de templos. Expõem-se prefeitos e governadores em confronto com o tratado do governo federal. O contexto, entretanto, nos leva a questionar acerca da motivação dessa série de reportagens. De qualquer modo, o que se pode enfatizar é que, durante a pior pandemia das últimas décadas, uma rede de televisão ligada a uma Igreja cristã representativa no contexto brasileiro utiliza a sua influência pública para forçar prefeitos e governadores para que flexibilizassem as restrições sobre atividades religiosas. Trata-se de algo que poderia afetar diretamente o aumento de casos de contágio de Covid-19 e, consequentemente, o número de mortes. Prefere-se esta postura, àquela de cuidado da vida humana de tal modo que se pudessem seguir todos os caminhos possíveis para a redução de contágios.

\section{Considerações finais}

O dado religioso é parte constituinte da análise do espaço público brasileiro. Esta constatação adquire significado também diante do estudo acerca do tempo pandêmico e seus desdobramentos na perspectiva religiosa. Com o presente artigo, se pretendeu demonstrar o quanto diferentes denominações religiosas, sobretudo evangélicas neopentecostais, têm exercitado a sua interlocução e presença em nível político, não raro, atuando em causa própria. O uso das mídias, nesse contexto, se torna um possível aporte estratégico para consolidação de narrativas. 
A liberdade religiosa, resguardada no contexto de um país formalmente laico, deveria ser protegida pelo Estado e suas instituições. Essa prerrogativa, atende as premissas das liberdades de consciência, de crença, de culto e de organização religiosa. Contudo, há que se notar que a liberdade religiosa não significa uma espécie de salvo conduto para que diferentes denominações realizem aquilo que bem entenderem. No contexto social, o que se espera das religiões é que corroborem para a construção de uma sociedade mais fraterna, justa, solidária e equitativa no horizonte da efetivação da dignidade humana.

No âmbito pandêmico, mesmo que pessoas se vejam limitadas em suas práticas de fé na perspectiva de uma interação coletiva ou comunitária, essa contingência precisa ser iluminada por um espectro maior que conflui para o cuidado de vidas. Que a economia e os serviços religiosos sigam atuando a qualquer custo, é o tipo de lógica que, por óbvio, contradiz as bases inerentes à própria fé que se busca defender. Chama a atenção que certos veículos de significativo impacto social, como no caso das redes abertas de televisão, sejam utilizadas para fomentar a flexibilização de atividades religiosas em detrimento da veiculação de recomendações técnicas ou cientificas e de exemplos e práticas efetivas de combate à pandemia.

Para além das questões ligadas ao saber jurídico, as pesquisas sociológicas, as evidências médicas e as particularidades de cunho religioso, as milhões de vítimas contaminadas e as centenas de milhares de mortos impõem, por certo, ao imaginário da sociedade brasileira uma dimensão simbólica muito clara sobre as atitudes das principais lideranças políticas e religiosas no Brasil. Os comportamentos, as condutas públicas, as palavras e a responsabilidade institucional, mostram uma postura muito distante daquilo que seria esperado em um momento no qual se enfraquecem os sentimentos de pertencimento às identidades coletivas, das responsabilidades compartilhadas, de segurança pessoal, de dignidade, em detrimento de um oportunismo demagógico e obscurantista.

Diante do que foi aqui apresentado, o que se evidencia é um tipo de religiosidade que desvaloriza o sofrimento humano e a ambiguidade da existência em razão do suporte alicerçado em uma narrativa elitista e alienante que se coaduna com outras expressões autoritárias no campo político e econômico. Os aparatos institucionais são utilizados em causa própria, não em favor do cuidado ou zelo pelas pessoas. Caso se queira evocar aqui alguma espécie de memória cristã, se poderia entabular uma menção ao modo como 
Jesus é apresentado e interpretado nos textos das primeiras comunidades cristãs. A lógica quenótica, de esvaziamento de si em favor dos outros, central para a cristologia no decorrer dos tempos, acaba ficando obnubilada.

Diante da aparente necessidade de manutenção das atividades religiosas e a consequente perpetuação de estruturas de poder e domínio sobre corpos e os imaginários, é, pois, pertinente questionar se alguns fiéis seriam, porventura, descartáveis? Ou, ainda, para utilizar um conceito anteriormente desenvolvido, seriam algumas pessoas "matáveis" para que a roda eclesial continue girando? Não basta apenas que tenhamos em nosso horizonte os ideais preconizados por Jesus de Nazaré. É preciso que as pessoas absorvam a lógica desta liderança para, a partir de nosso tempo, acentuar práticas e comportamentos éticos que permitam entabular um mundo com mais solidariedade. Afinal, de que serve uma diretriz religiosa se ela não repercute o bem comum ao não postular parâmetros balizados pela empatia e humanidade?

Ao fim e ao cabo, sempre de novo, as palavras do teólogo reformado suíço, Karl Barth (1886-1968), podem ser ecoadas diante da presença pública das igrejas também neste contexto desafiador:

Nesse caos a comunidade cristã fará a si mesma a pergunta se ela já forneceu à comunidade civil a prova do espírito e da força, representou e proclamou a Jesus Cristo frente ao mundo de forma tal que já possa esperar, de sua parte, ser considerada fator importante, interessante e benéfico na vida pública (BARTH, 2018, p. 304).

\section{Referências}

ALMEIDA, R.; GUERREIRO, C. Templos em tempo de pandemia. Boletim n ${ }^{\mathbf{o}} 19$ - Ciências Sociais e Coronavírus. Disponível em: https://cienciapolitica.org.br/noticias/2020/04/ boletim-19-templos-tempo-pandemia. Acesso em: 19 Out. 2020.

ALVES, R. Protestantismo e Repressão. São Paulo: Ática, 1979.

ASSELIN, V. Grilagem: corrupção e violência em terras do Carajás. Imperatriz: Ética, 2009. ÁVILA, H. Teoria dos Princípios: da definição à aplicação dos princípios jurídicos. São Paulo: Malheiros, 2004.

BARTH, K. Dádiva e louvor: ensaios teológicos de Karl Barth. 4. ed. São Leopoldo: Sinodal/ EST, 2018.

BERGER, P. Os múltiplos Altares da Modernidade: rumo a um paradigma da religião numa época pluralista. Petrópolis: Vozes, 2017. 
BIRMAN, P. (Org.). Religião e Espaço Público. São Paulo: Attar, 2003.

BLOG DO HIEL LEVY. Os irmãos Câmara são aliados do governo federal. 22 nov. 2019. Disponível em: https://blogdohiellevy.com.br/irmaos-camara-preparam-demonstracao-deforca-para-bolsonaro-e-podem-influir-no-novo-partido/. Acesso em: 18 Out. 2020.

BONAVIDES, P.; ANDRADE, P. de. História Constitucional do Brasil. Rio de Janeiro: Paz e Terra, 1991. (Volume 3).

BRASIL. Constituição da República Federativa do Brasil. Disponível em:<http://www. planalto.gov.br/ccivil_03/constituicao/constituicao.htm>. Acesso em: 05 de Out. 2020.

CAMPOS, L. S. Os Evangélicos, o Golpe e a Ditadura: O Irresistível Canto das Sereias Autoritárias. In: DIAS, Z. M. (Org.). Memórias ecumênicas protestantes - Os protestantes e a Ditadura: colaboração e resistência. Rio de Janeiro: KOINONIA Presença Ecumênica e Serviço, 2014. p. 177-191.

CATRACA LIVRE. Com uma criança, Bolsonaro dá risada sobre as queimadas no Pantanal. 28 set. 2020. Redação. Disponível em: https://catracalivre.com.br/cidadania/com-uma-criancabolsonaro-da-risada-sobre-as-queimadas-no-pantanal/. Acesso em: 02 Nov. 2020.

CATROGA, F. Entre Deuses e Césares: Secularização, Laicidade e Religião Civil. Coimbra: Almedina, 2006.

COELHO, A. da S.; SUNG, J. M. Capitalismo como religião: uma revisão teórica da relação entre religião e economia na modernidade. Horizonte, v. 17, n. 53, p. 651-675, 2019.

CORREIO BRAZILIENSE. Estudos sinalizam que a fé pode sim ajudar a superar doenças. 07 mar. 2020. Disponível em: https://www.correiobraziliense.com.br/app/noticia/ ciencia-e-saude/2010/03/07/interna_ciencia_saude,178036/estudos-sinalizam-que-a-fe-podesim-ajudar-a-superar-doencas.shtml. Acesso em: 18 Out. 2020.

CPI DA PANDEMIA. Relatório Final. 26 out. 2021. Disponível em: https://senadofederalmy.sharepoint.com/personal/cpipandemia_arquivos_senado_leg_br/_layouts/15/onedrive. aspx $\mathrm{id}=\% 2 \mathrm{Fpersonal} \% 2 \mathrm{Fcpipandemia} \% 5 \mathrm{Farquivos} \% 5 \mathrm{Fsenado} \% 5 \mathrm{Fleg} \% 5 \mathrm{Fbr} \% 2 \mathrm{FDocu}$ ments\%2FRelat $\%$ C3\%B3rio\%20Final\%2FRelatorio\%5FFinal\%5Faprovado\%2Epdf\&pare $\mathrm{nt}=\% 2 \mathrm{Fpersonal} \% 2 \mathrm{Fcpipandemia} \% 5$ Farquivos $\% 5 \mathrm{Fsenado} \% 5 \mathrm{Fleg} \% 5 \mathrm{Fbr} \% 2 \mathrm{FD}$ ocuments \%2FRelat\%C3\%B3rio\%20Final. Acesso em: 06 Nov. 2021.

CUNHA, M. do N. Fundamentalismos, crise da democracia e ameaça aos direitos humanos na América do Sul: tendências e desafios para a ação. Salvador: KOINONIA Presença Ecumênica e Serviço, 2020.

CUNHA, M. do . Religião e política: fundamentalismos evangélicos no Brasil contemporâneo e suas expressões pelas mídias. In: KUZMA, C.; CAPPELLI, M. (Org.). Religião, ética e política. São Paulo: Paulinas, 2018.

DÁVILA, Jerry. Diploma de brancura: política social e racial no Brasil 1917-1945. São Paulo: Editora da UNESP, 2006.

DIP, A. (et. al.). O lobby dos evangélicos contra o fechamento das igrejas. Agência Pública. 7 abr. 2020. Disponível em: https://apublica.org/2020/04/o-lobby-dos-evangelicos-contrao-fechamento-das-igrejas/. Acesso em: 21 Out. 2020. 
DOMINGO ESPETACULAR. Fechamento de espaços religiosos limita a prática da fé na pandemia. Canal do YouTube. 2 ago. 2020. Disponível em: https://www.youtube.com/ watch?v=m6_lc4kG6RY. Acesso em: 03 Ago. 2020.

FRESTON, Paul. Protestante e política no Brasil: da Constituinte ao impeachment. Tese (Doutorado em Sociologia). Unicamp, 1993.

G1. Brasil ultrapassa 609 mil mortes por Covid, média móvel fica abaixo de 300 pelo $5^{\circ}$ dia. 05 nov. 2021. Disponível em: https:/g1.globo.com/saude/coronavirus/noticia/2021/11/05/ brasil-ultrapassa-609-mil-mortes-por-covid-media-movel-fica-abaixo-de-300-pelo-5o-dia. ghtml. Acesso em: 06 Nov. 2021.

GALEANO, E. As veias abertas da América Latina. Porto Alegre: L\&PM, 2015.

GIUMBELLI, E. O Acordo Brasil - Santa Sé e as Relações entre Estado, Sociedade e Religião. Ciencias Sociales y Religión, ano 13, n. 14, p. 119-143, 2011.

HABERMAS, J.; RATZINGER, J. Dialética da secularização: sobre razão e religião. São Paulo: Ideias \& Letras, 2007.

HUACO, M. A laicidade como princípio constitucional do Estado de Direito. In: LOREA, R. A. (Org.). Em defesa das liberdades laicas. Porto Alegre: Livraria do Advogado, 2008. p. 33-80.

INSTITUTO BRASILEIRO DE GEOGRAFIA E ESTATÍSTICA. IBGE. Panorama. 2017. Disponível em: https://cidades.ibge.gov.br/brasil/panorama. Acesso em: 19 Out. 2020.

JORNAL DA RECORD. Fechamento de templos e igrejas pode ter impacto nas eleições municipais deste ano. Canal do YouTube. 30 jul. 2020. Disponível em: https://www.youtube. com/watch?v=ZU738VOllkk. Acesso em: 02 Ago. 2020.

JORNAL DA RECORD. Fechamento de templos e igrejas prejudica ações sociais durante a pandemia. Canal do YouTube. 28 jul. 2020. Disponível em: https://www.youtube.com/ watch?v=Cioy-L03F88. Acesso em: 02 Ago. 2020.

JORNAL DA RECORD. Live JR aborda a necessidade da reabertura de espaços religiosos; veja na íntegra. Canal do YouTube. 31 jul. 2020. Disponível em: https://www.youtube.com/ watch?v=x16I4bzqFR0. Acesso em: 02 Ago. 2020.

JORNAL DA RECORD. Maioria dos brasileiros é a favor da abertura dos espaços religiosos, aponta pesquisa. Canal do YouTube. 31 jul. 2020. Disponível em: https://www.youtube.com/ watch?v=OqcQ9HxNrKU. Acesso em: 03 Ago. 2020.

JORNAL DA RECORD. Na maior crise do século, fé é aliada importante para a saúde do corpo e da mente. Canal do YouTube. 29 jul. 2020. Disponível em: https://www.youtube. com/watch?v=C1r7o5GEHWU. Acesso em: 03 Ago. 2020.

JORNAL DA RECORD. Prefeitos impedem ida a templos e igrejas. Canal do YouTube. 27 jul. 2020. Disponível em: https://www.youtube.com/watch?v=ojjGbUlte1s. Acesso em: 02 Ago. 2020.

JURKEWICZ, R. S. Violência clerical: abuso sexual de mulheres por padres no Brasil. 2006. 199p. Tese (Doutorado em Ciências da Religião). Pontifícia Universidade Católica de São Paulo, São Paulo, SP. 
LEITE, F. C. Estado e Religião. A Liberdade Religiosa no Brasil. Curitiba: Juruá, 2014.

MARIANO, R. Análise sociológica do crescimento pentecostal no Brasil. 2001. 253p. Tese (Doutorado em Sociologia) - Universidade de São Paulo, São Paulo, SP.

MARIANO, R. Neopentecostais: sociologia do Novo Pentecostalismo no Brasil. São Paulo: Loyola, 2005.

MARTINS, J. de S. Fronteira: a degradação do outro nos confins do humano. São Paulo: Contexto, 2019.

MBEmBE, A. Necropolítica. Arte e Ensaios. Revista do PPGAV/EBA/UFRJ, n. 32, p. 122-151, 2016.

MELLO, I. Flávio e Carlos Bolsonaro se filiam a partido ligado à Igreja Universal. 27 mar. 2020. Disponível em: https://noticias.uol.com.br/politica/ultimas-noticias/2020/03/27/flavioe-carlos-bolsonaro-se-filiama-partido-ligado-a-igreja-universal.htm. Acesso em: 21 Out. 2020.

MENDES, N. Imperatriz, “a terra da pistolagem”: assassinatos, memórias, fatos, representações e lógicas sociais. Imperatriz- MA: Ética Editora, 2016.

MONTERO, P. Secularização e espaço público: a reinvenção do pluralismo religioso no Brasil. Etnográfica, 13 (1), p. 7-16, 2009.

MST. Fazendeiro é condenado pela morte de Padre Josimo. 16 set. 2010. Disponível em: https://mst.org.br/2010/09/16/fazendeiro-e-condenado-pela-morte-de-padre-josimo/. Acesso em: 06 Nov. 2021.

NASCIMENTO, G. Sem fiéis, sem dízimo, sem palanque: epidemia esvazia templos, e igrejas neopentecostais não conseguem pagar horários alugados em emissoras de TV. Revista Piauí. 29 abr. 2020. Disponível em: https://piaui.folha.uol.com.br/sem-fieis-sem-dizimo-sempalanque/. Acesso em: 21 Out. 2020.

ORO, I. P. O outro é o demônio: uma análise sociológica do fundamentalismo. São Paulo: Paulus, 1996.

R7. Saiba quais cidades do Brasil continuam sem cultos religiosos. 30 jul. 2020. Disponível em: https://noticias.r7.com/brasil/saiba-quais-cidades-do-brasil-continuam-semcultos-religiosos-31072020. Acesso em: 18 Out. 2020.

RIGALI, N. J. Moral theology and church responses to sexual abuse. Horizons, v. 34, n. 2, p. 183-204, 2007.

RODRIGUES, E. B. Estado Laico e Símbolos Religiosos no Brasil: As Relações entre Estado e Religião no Constitucionalismo Contemporâneo. Curitiba: Juruá, 2014.

SANTOS, L. A.; ALMEIDA, A. J. S. Trincheiras da verdade: o Fundamentalismo Evangélico e a Ditadura Militar Brasileira. Mnemonise Revista, v. 5, p. 130-147, 2014.

SARMENTO, D. O Crucifixo nos Tribunais e a Laicidade do Estado. Revista de Direito do Estado. Vol. 8, p. 75-90, 2007. 
SCHRITZMEYER, A. L. P. Sortilégio de Saberes: curandeiros e juízes nos tribunais brasileiros (1900-1990). São Paulo: IBCCRIM, 2004.

SENADO FEDERAL. Pesquisas apontam que milhares de mortes por Covid poderiam ter sido evitadas no Brasil. 24 jun. 2021. Disponível em: https://www12.senado.leg.br/noticias/ materias/2021/06/24/pesquisas-apontam-que-milhares-de-mortes-por-covid-poderiam-tersido-evitadas-no-brasil. Acesso em: 09 Jul. 2021.

SOUZA, S. D. de; OSHIRO, C. P. Mulheres evangélicas e violência doméstica: o que o poder público e a igreja têm a ver com isso? Caminhos, v. 16, n. 2, p. 203-219, 2018.

STEIL, C. A. Pluralismo, Modernidade e Tradição: Transformações no Campo Religioso. Ciencias Sociales Y Religión, año 3, n. 3, p. 115-129, 2001.

UNIVERSAL. Fechar uma igreja é como fechar um hospital. 16 ago. 2020. Disponível em: https://www.universal.org/blog/2020/08/16/fechar-uma-igreja-e-como-fechar-um-hospital/. Acesso em: 18 Out. 2020.

VELHO, O. G. Capitalismo Autoritário e campesinato: um estudo comparativo a partir da fronteira em movimento. Centro Edelstein de Pesquisas Sociais, 2009.

WALLERSTEIN, I. Análise dos sistemas mundiais. GIDENS, A.; TURNER, J. Teoria Social Hoje. São Paulo: UNESP, 1999. p. 445-470.

WEBER, M. A ética protestante e o espírito do capitalismo. São Paulo: Companhia das Letras, 2004.

WEINGARTNER, J. N. Liberdade Religiosa na Constituição: fundamentalismo, pluralismo, crenças, cultos. Porto Alegre: Livraria do Advogado, 2007.

Submetido em: 14-11-2021

Aceito em: 21-1-2022 